\title{
Analysis of rainfall-triggered landslide in Baleagung Village, Magelang Regency, Central Java
}

\author{
Putria Widya Budiarti ${ }^{1 *}$, Teuku Faisal Fathani ${ }^{1,2}$, and Fikri Faris ${ }^{1,2}$ \\ ${ }^{1}$ Department of Civil and Environmental Engineering, Faculty of Engineering, Universitas Gadjah Mada, Yogyakarta, Indonesia \\ ${ }^{2}$ Center for Disaster Mitigation and Technological Innovation (GAMA-InaTEK), Universitas Gadjah Mada, Yogyakarta, Indonesia.
}

\begin{abstract}
The majority of Magelang Regency is considered as intermediate and high susceptible areas against landslide. As happened in Baleagung Village in January 2018, a landslide has damaged local residency buildings. The landslide occurred because of high-intensity rainfall on the day before. Meanwhile, cracks formed in several areas that were indicated by the slope around the village were still actively moving. Therefore, mitigation is urgently needed to minimize the risk of further landslide movement. This study aimed to analyze the mechanism of ground movement at Baleagung Village which was affected by rainfall. This research was conducted by using back-analysis method to determine the initial groundwater level conditions and its effect on the slope stability. Soil parameters were obtained by laboratory testing and permeability tests in the field. Subsequently, rainfall data was collected from Himawari-8 satellite and used as the data input parameter for numerical analysis using SEEP/W and SLOPE/W. The results obtained from back-analysis showed that rainfall infiltration into the soil affected the degradation of safety factor value that was caused by the increase of pore-water pressure and the decrease of effective stress in a certain period. The degradation of safety factor was caused by the increasing of soil saturation degree when water infiltrated into the ground.
\end{abstract}

Keywords: landslide susceptibility, rainfall intensity, groundwater level, slope stability, landslide mitigation.

\section{Introduction}

As the most populous region in Indonesia, Java Island frequently suffers from landslide that had caused a tremendous amount of damage both on human life and material loss. According to PVMBG (Centre of Volcanology and Geological Hazard Mitigation) records, the majority area of Java Island is vulnerable to landslide, especially Magelang Regency, where most of the areas are categorized as intermediate and high susceptibility zone [1]. Baleagung Village is classified as a high susceptibility zone. The village is located at Grabag District, 20 kilometers away from the district capital city Magelang, Central Java Province. It is geographically situated at $110^{\circ} 18^{\prime} 19^{\prime \prime} \mathrm{E}$ and $7^{\circ} 23^{\prime}$ 32.3" S. The residential areas are located at the hillside of Andong Mountain. Kupen Sub-village is part of Baleagung Village, Magelang Regency, and its residents live surrounding the area at the base of the hill (Figure 1). Two hundred and fifty families or almost 1200 local residents live at Kupen Sub-village. The total area is 132 hectares, with 8.66 hectares are being used as a residency area. Most of the areas are hills, which lead the sub-village prone to landslides.

According to BPBD (Local Disaster Management Agency), a landslide occurred at Kupen Sub-village on 19 January 2018 at 05.00 a.m. The chronological event started from a heavy rainfall in Grabag District on January $18^{\text {th }} 2018$ that caused a 7 meter $\times 10$ meter (high $\times$ wide) cliff slide and dragged a great amount of bamboo groves. Furthermore, the soil avalanche and bamboo groves hit several houses and caused a tremendous damage [2].

During the field observation, the slope movement can be located by the indications of cracks surrounding the slope (Figure 2) and several buildings. Therefore, mitigation is needed to minimize the risk of further landslide movement. Mitigation effort or disaster countermeasure is divided into two parts, structural and non-structural mitigation [3]. Structural mitigation could be conducted in the form of structural reinforcement, slope protection, drainage system, sabo dam construction, etc. Meanwhile, one of non-structural mitigation effort is by designing a monitoring and early warning system in the susceptible area.

\footnotetext{
${ }^{*}$ Corresponding author: putriawidya@mail.ugm.ac.id
} 


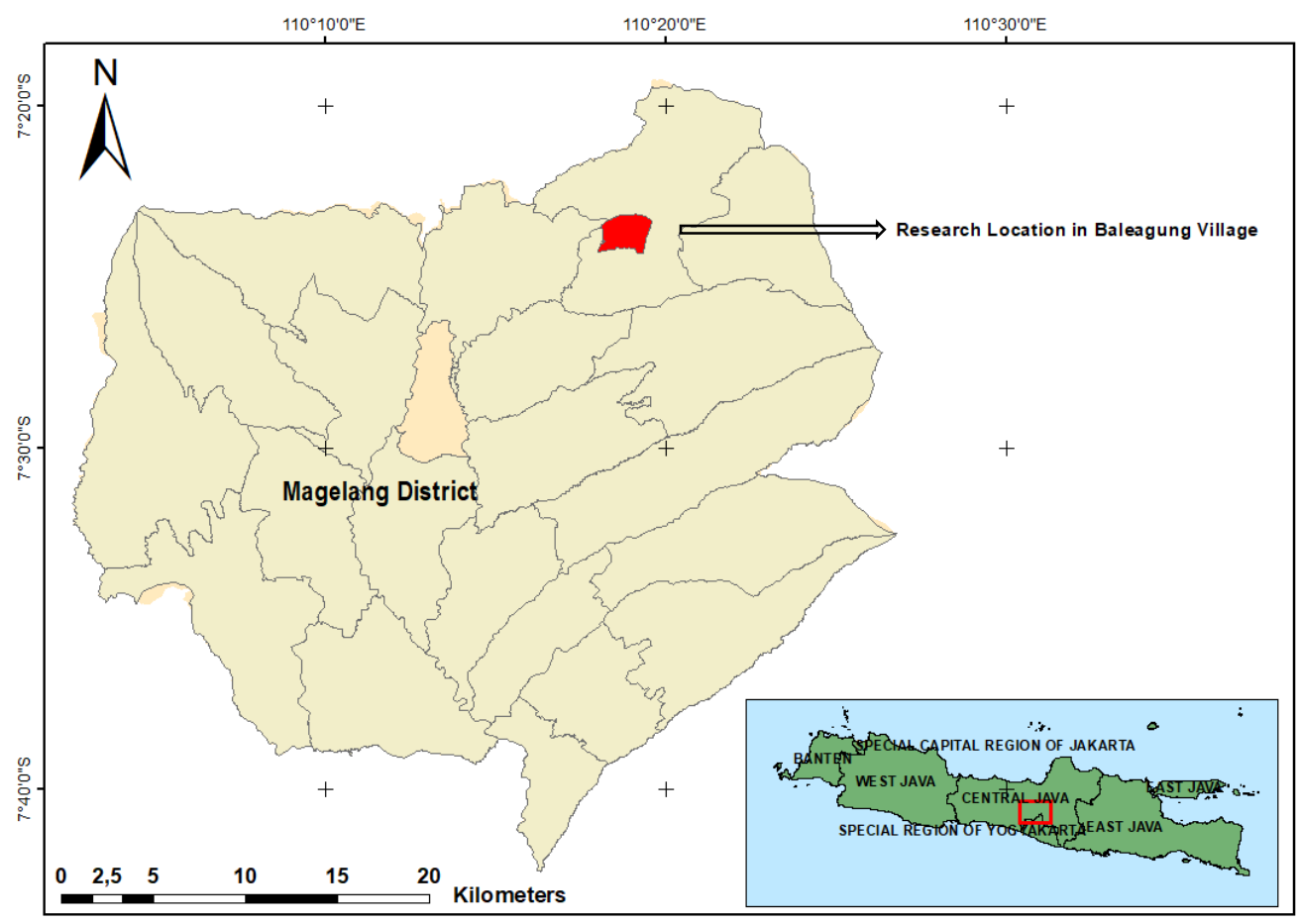

Fig. 1. Research location

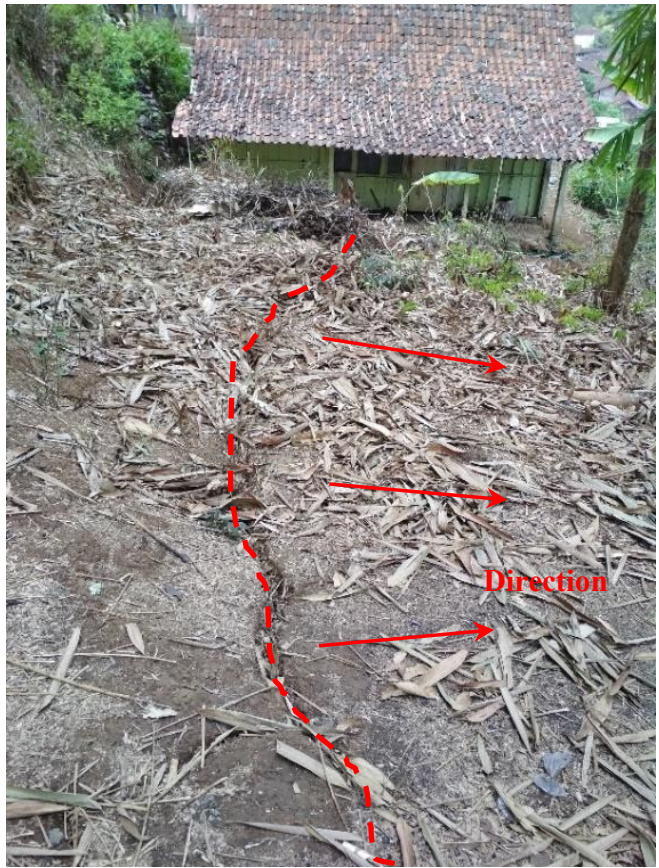

Fig. 2. Crack surrounding Kupen Sub-village

Several researchers have conducted studies related to the effect of rainfall-induced landslide. Ariesta studied the effect of groundwater level conditions and rainfall wetting on the stability of the slope with a hydraulic conductivity approach using the Geostudio software for Ponorogo landslide case study [4]. Bui et al. conducted a landslide risk assessment to design a monitoring and early warning system in Kulonprogo with a hydrological analysis approach [5]. Faris and Fathani carried out an analysis of early warning criteria as one of the nonstructural mitigation measures by modeling the infiltration of rainfall into the ground-which affected the fluctuations of groundwater levels in Banjarnegara-using the tank model [6]. Naing et al. conducted research about the mechanism of soil movement in the Kulonprogo Regency and analyzed the effect of groundwater fluctuations on the stability of the slopes using a tank model approach [7].

Based on previous studies, there is a necessity to analyze the mechanism of soil movement and the effect of rainfall on the stability of the slope by modeling its hydraulic conductivity. The expected benefit of this research is to improve the knowledge about landslide mechanisms in a particular area and to provide information to the community and local government related to mitigation efforts and preparedness to landslide disaster that may happen anytime in Kupen Sub-village, Baleagung Village, Magelang Regency.

\section{Rainfall-Triggered Landslide}

Rainfall is one of landslide triggering factors. Rainfall infiltration into the soil could affect slope stability since it can increase the pore-water pressure on the soil. Furthermore, positive water pressure causes capillarity and increases the groundwater level [8]. The rising of groundwater level increases soil mass and degrades soil inter-particle bonds [9]. Soil mass escalation and degradation of soil inter-particle weaken the soil strength and makes it susceptible to landslide.

Frequently, landslide occurred on skewed surfaces and is affected by gravitational components. If the forces (load) caused by gravitational components are sufficient and enough to overcome the total shear resistance on its slipped plane, then landslide would occur [9]. High saturation on soil weakens soil inter- 
particle bonds, hence lessens soil shear strength. Subsequently, this particular situation made the soil movement unstable [10].

In keeping with the hydrological point of view, the groundwater level is significantly influenced by the rainfall, and the infiltration rate is affected by soil surface conditions. In addition, more cracks on the avalanche body would result to easier water infiltration [6]. When the rain wets the soil surface, there is a juncture of time between the rainfall and groundwater level change due to rainfall infiltration. This particular condition can be counted as a rainfall effect with soil movement. Peranić conducted an approach towards water infiltration factor and slope stability [11], i.e. rain infiltration analysis affecting the slope stability with hydraulic conductivity approach and Soil Water Retention Curve (SWRC). SWRC is an approach used to model groundwater flows. Infiltration analysis is obtained through the hydraulic conductivity equation and parameter. Therefore, the water infiltration's effect on the slope stability could be determined.

\section{Research Method}

The data used in this research were observational monitoring data and the slope geometry from an aerial photograph, whereas the soil index properties and engineering properties were determined by field survey and laboratory testing. Other data used in the analysis are rainfall data from Himawari-8 Satellite and geoelectrical resistivity data.

\subsection{Study Area}

Based on Digital Elevation Model (DEM) from aerial photographs, Kupen Sub-village at Baleagung Village has the slope steepness value ranging from $25 \%$ to $96 \%$ From Table 1, the slope is classified as 'steep' to 'very steep'. From field observation and aerial photography mapping (Figure 3), it is shown that the land use on the research area commonly are for plantation land, shrubs, wet rice fields, and residency. The plantation land is generally used as a bamboo plantation by the local community, which does not have strong roots to accommodate soil movement. To observe landslide activity, two monitoring devices i.e. an extensometer and rainfall station, were used and its location are shown in Figure 3.

Table 1. Slope steepness classification [12]

\begin{tabular}{ccl}
\hline Class & Slope Steepness (\%) & \multicolumn{1}{c}{ Category } \\
\hline I & $0-8$ & Plane \\
II & $>8-15$ & Skewed \\
III & $>15-25$ & Slightly Steep \\
IV & $>25-45$ & Steep \\
V & $>45$ & Very Steep \\
\hline
\end{tabular}

\subsection{Soil Properties}

Soil sampling in the field was carried out at two points, $\mathrm{B} 1$ and B2. The detailed location of the borehole is shown in Figure 3. Through laboratory testing, the soil index properties such as water content, Atterberg limits, specific gravity, and grain distribution analysis of samples were collected.

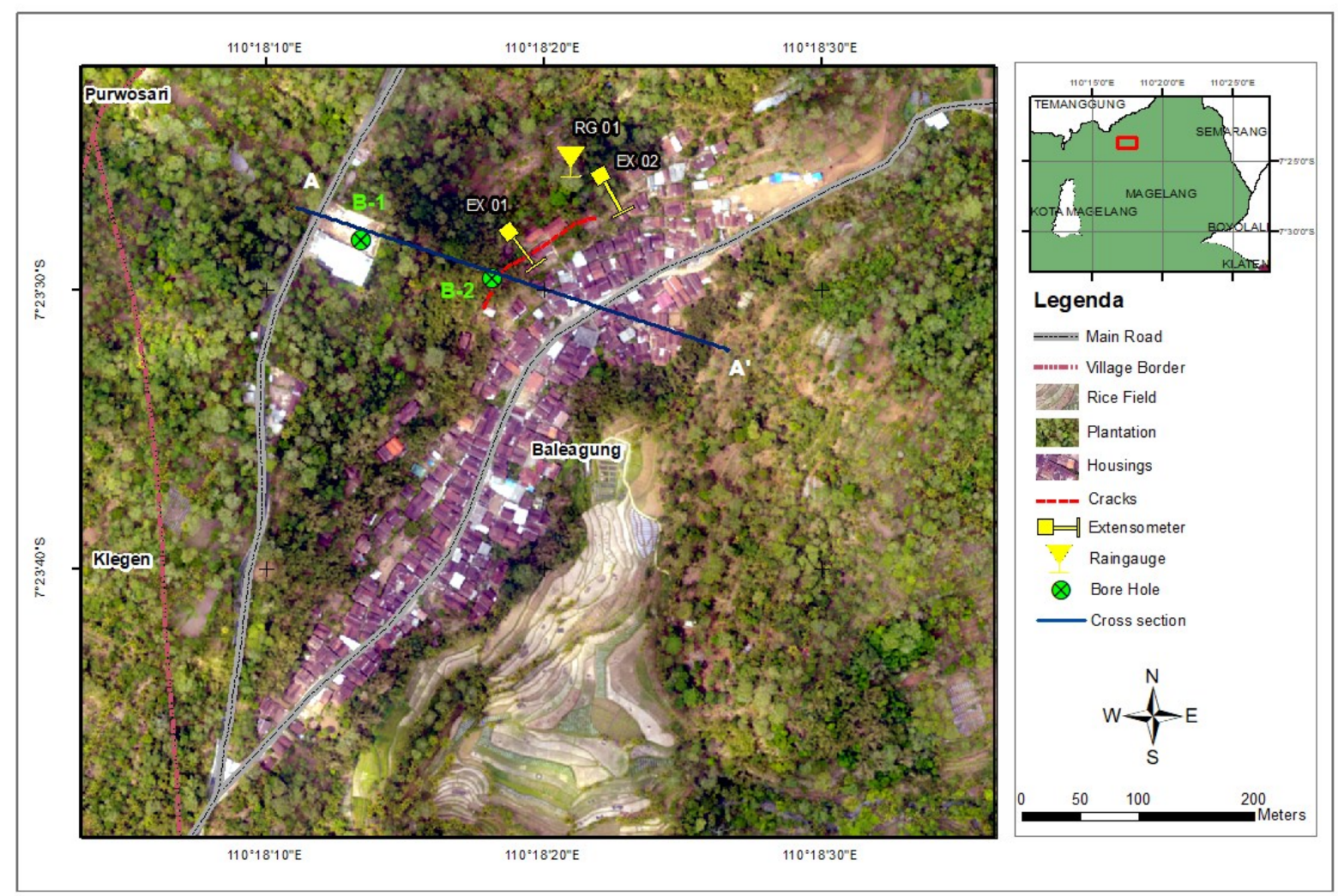

Fig. 3. Aerial photograph of the research area 
Soil shear strength was measured using the triaxial method. The laboratory test results are summarized in Table 2. Where $w_{n}$ is water content, $G_{s}$ is specific gravity, LL is liquid limit, PL is plastic limit, PI is plasticity index and LI is liquidity index.

In accordance with Unified Soil Classification (USCS), the soil was categorized as silt with low plasticity (ML), inorganic silt and very fine sand, rock powder, or fine silt or clay sand [13].

Table 2. Soil Index Properties

\begin{tabular}{llllllll}
\hline Point & $\boldsymbol{w}_{\boldsymbol{n}} \%$ & $\boldsymbol{G}_{\boldsymbol{s}}$ & $\begin{array}{l}\text { LL } \\
\boldsymbol{\%}\end{array}$ & $\begin{array}{l}\text { PL } \\
\boldsymbol{\%}\end{array}$ & $\begin{array}{l}\text { PI } \\
\text { \% }\end{array}$ & LI & USCS \\
\hline B1 & 49.5 & 2.7 & 48.7 & 34.2 & 14.5 & 1.1 & ML \\
\hline B2 & 81.9 & 2.8 & 45.8 & 34.5 & 11.3 & 4.2 & ML \\
\hline
\end{tabular}

Soil shear strength and unit weight value are shown in Table 3, where $\gamma_{d r y}, \gamma_{b u l k}, \gamma_{\text {sat }}$ are dry volume weight, bulk volume weight and saturated volume weight of the soil, respectively. Meanwhile, the shear strength of the soil is expressed as cohesion (c) and internal friction angle $(\varphi)$.

Table 3. Unit weight and shear strength parameters

\begin{tabular}{|c|c|c|c|c|c|}
\hline \multirow{2}{*}{ Point } & \multirow{2}{*}{$\begin{array}{c}\gamma_{d r y} \\
\left(\mathbf{k N} / \mathrm{m}^{3}\right)\end{array}$} & \multirow{2}{*}{$\begin{array}{c}\gamma_{\text {bulk }} \\
\left(\mathbf{k N} / \mathbf{m}^{3}\right)\end{array}$} & \multirow{2}{*}{$\begin{array}{c}\gamma_{s a t} \\
\left(\mathbf{k N} / \mathbf{m}^{3}\right)\end{array}$} & \multicolumn{2}{|c|}{$\begin{array}{l}\text { Shear Strength } \\
\text { Parameters }\end{array}$} \\
\hline & & & & $c\left(\mathrm{kN} / \mathrm{m}^{2}\right)$ & $\varphi\left(^{\circ}\right)$ \\
\hline B1 & 11.67 & 17.44 & 17.16 & 11.54 & 15.72 \\
\hline B2 & 8.63 & 14.65 & 15.39 & 11.68 & 18.55 \\
\hline
\end{tabular}

Soil permeability test (on-field) results by using Phillip-Dunne falling-head method at borehole points of B1 and B2 are shown in Table 4 [14].

Table 4. Soil Permeability

\begin{tabular}{lll}
\hline Point & $\boldsymbol{k}_{\boldsymbol{s}}(\mathbf{m} / \mathbf{s})$ & $\boldsymbol{k}_{\boldsymbol{s}}(\mathbf{c m} / \mathbf{s})$ \\
\hline B1 & $2.65 \times 10^{-6}$ & 0.000265 \\
\hline B2 & $4.43 \times 10^{-5}$ & 0.004434 \\
\hline
\end{tabular}

According to Das [15], the permeability $\left(k_{s}\right)$ on point B1 is $0.001-0.00001 \mathrm{~cm} / \mathrm{s}$, therefore the soil type can be categorized as silty clay. Furthermore, the $k_{s}$ value on point B2 is 0.01-0.001 soil type can be categorized as fine sand or sandy.

\section{Rainfall Analysis}

Rainfall analysis was derived from Himawari- 8 satellite on the period of January $1^{\text {st }}$ to $19^{\text {th }}$ of 2018 before the landslide took place. The landslide was occurred at 05:00 a.m. on January $19^{\text {th }} 2018$. In order to obtain rainfall analysis from satellite imagery, a mean algebraic method was used. Since the research field study was \pm $4.53 \mathrm{~km}^{2}$ and spatial imagery resolution of Himawari-8 is $4 \mathrm{~km}$, using the mean algebraic method would be sufficient to obtain regional rainfall information. Table 5 presents the rainfall intensity and precipitation rate [16].

Table 5. Rainfall intensity [16]

\begin{tabular}{lll}
\hline Rainfall Intensity & \multicolumn{2}{c}{$(\mathbf{m m})$} \\
\cline { 2 - 3 } & 1 hour & 24 hours \\
\hline Very light rain & $<1$ & $<5$ \\
Light rain & $1-5$ & $5-20$ \\
Normal rain & $5-10$ & $20-50$ \\
Heavy rain & $10-20$ & $50-100$ \\
Weighty rain & $>20$ & $>100$ \\
\hline
\end{tabular}

According to Figure 4, it is clarified that the rainfall level was quite high before the landslide occurred. As shown in Table 6, that at a day before the landslide, daily rainfall accumulation reached $54.81 \mathrm{~mm}$. A few days before the event, on January $3^{\text {rd }}$ and $4^{\text {th }}$ January, daily rainfall accumulation reached $60.69 \mathrm{~mm}$ and 82.03, and it was categorized as heavy rain.

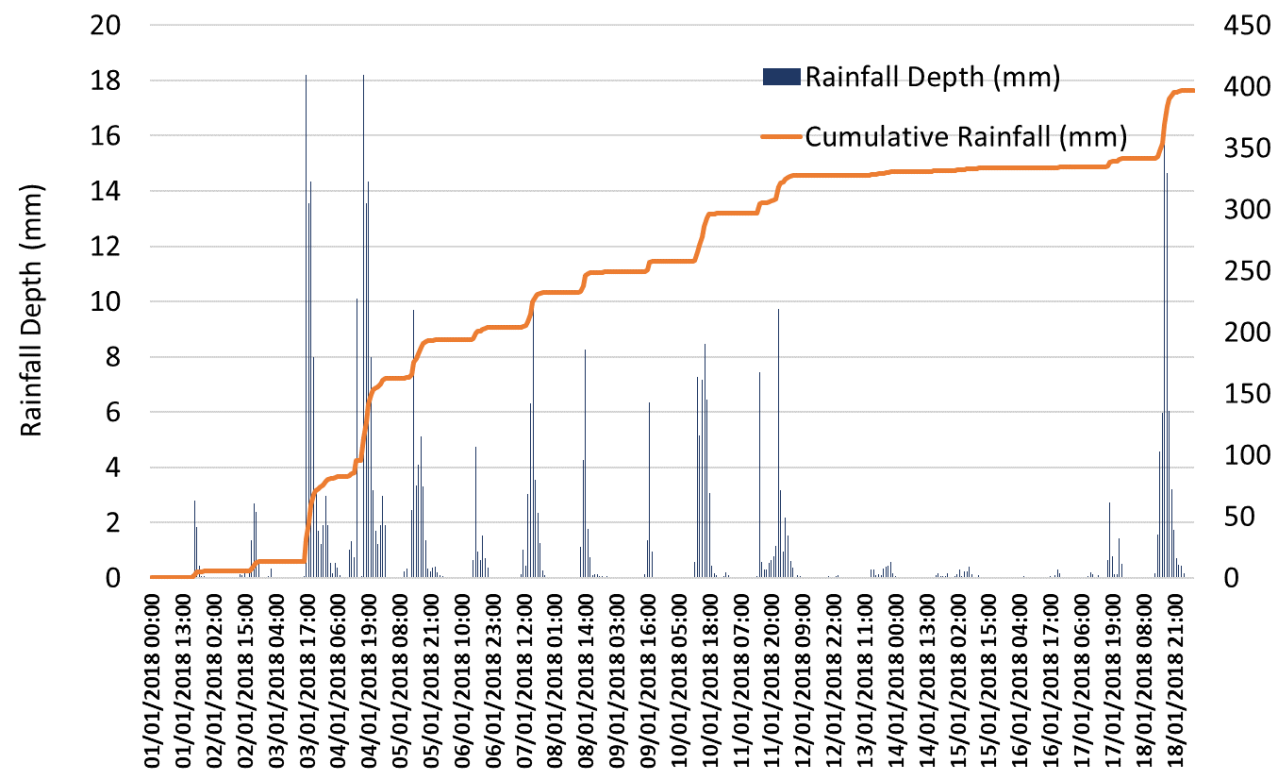

Fig. 4. Rainfall at Baleagung Village on 1-19 January 2018 
Table 6. Regional rainfall at Baleagung village on 1-19 January 2018

\begin{tabular}{cccc}
\hline Date & $\begin{array}{c}\text { Rainfall } \\
\text { Intensity } \\
(\mathbf{m m})\end{array}$ & Date & $\begin{array}{c}\text { Rainfall } \\
\text { Intensity } \\
(\mathbf{m m})\end{array}$ \\
\hline 1 & 5.31 & 11 & 21.96 \\
2 & 7.75 & 12 & 9.24 \\
3 & 60.69 & 13 & 3.11 \\
4 & 82.03 & 14 & 0.88 \\
5 & 38.04 & 15 & 1.79 \\
6 & 10.01 & 16 & 0.76 \\
7 & 28.39 & 17 & 6.98 \\
8 & 16.72 & 18 & 54.81 \\
9 & 8.76 & 19 & 0.59 \\
10 & 38.87 & & \\
\hline
\end{tabular}

\section{Results and Discussion}

\subsection{Landslide Modelling}

Landslide simulation was started with the slope geometrics determination at the most critical crosssection, as shown in Figure 3 (cross-section A-A'). The model analysis of this study was SEEP/W and SLOPE/W. Each material parameter was defined according to its analysis (Table 7). SEEP/W with saturated/unsaturated material model was being used for infiltration and rainfall wetting effect analysis. Hydraulic properties and water content for each layer were inputted.

In this analysis, the groundwater conditions were assumed as an approximation from geo-electrical resistivity results. On geo-electrical resistivity results, the water-saturated condition average was 30-40 meters under the ground surface. Therefore, the model was built upon these geo-electric results. The SEEP/W analysis was transient since it was based on the available rainfall data, i.e. monitoring the groundwater level conditions 19 days before the landslide disaster occurred at Kupen Sub-village.

The slope stability analysis was carried out using SLOPE/W with parent analysis resulted from SEEP/W. The material properties were derived from laboratory testing. The slope model is shown in Figure 5, whereas the Morgenstern-Price method was used in this study. The chosen analysis type was the transient analysis method with initial head/pore-water pressure from parent analysis. Therefore, the results from SEEP/W could be used in SLOPE/W. Table 7 clusters the parameters that were used in the software.

The boundary condition of current modeling was rainfall data. The average rainfall data was calculated from Himawari-8 imagery for 19 days before the landslide event. Slip surface was described using entry and exit range. The entry was a point in the left (top of the slope), i.e. a point indicated as the landslide crown, and an exit range was being made to a certain distance estimated as the landslide base region.

Table 7. Input parameter in the numerical analysis

\begin{tabular}{|c|c|}
\hline SEEP/W & SLOPE/W \\
\hline $\begin{array}{l}\text { Materials } \\
\text { - Soil permeability value } \\
\text { - Negative pore-water } \\
\text { pressure value } \\
\text { - Soil properties indexes } \\
\text { value }\end{array}$ & $\begin{array}{l}\text { Materials } \\
\text { - Shear strength parameter } \\
\text { (Mohr-Coulomb) } \\
\text { - Negative pore-water } \\
\text { pressure value } \\
\text { - Soil properties indexes and } \\
\text { shear strength values }\end{array}$ \\
\hline $\begin{array}{l}\text { Analysis } \\
\text { - Transient analysis } \\
\text { method } \\
\text { - Time }\end{array}$ & $\begin{array}{l}\text { Analysis } \\
\text { - Analysis method: MPM } \\
\text { - SEEP/W infiltration results }\end{array}$ \\
\hline $\begin{array}{l}\text { Boundary Condition } \\
\text { - Rainfall data (Rain flux } \\
\text { unit) }\end{array}$ & \\
\hline
\end{tabular}

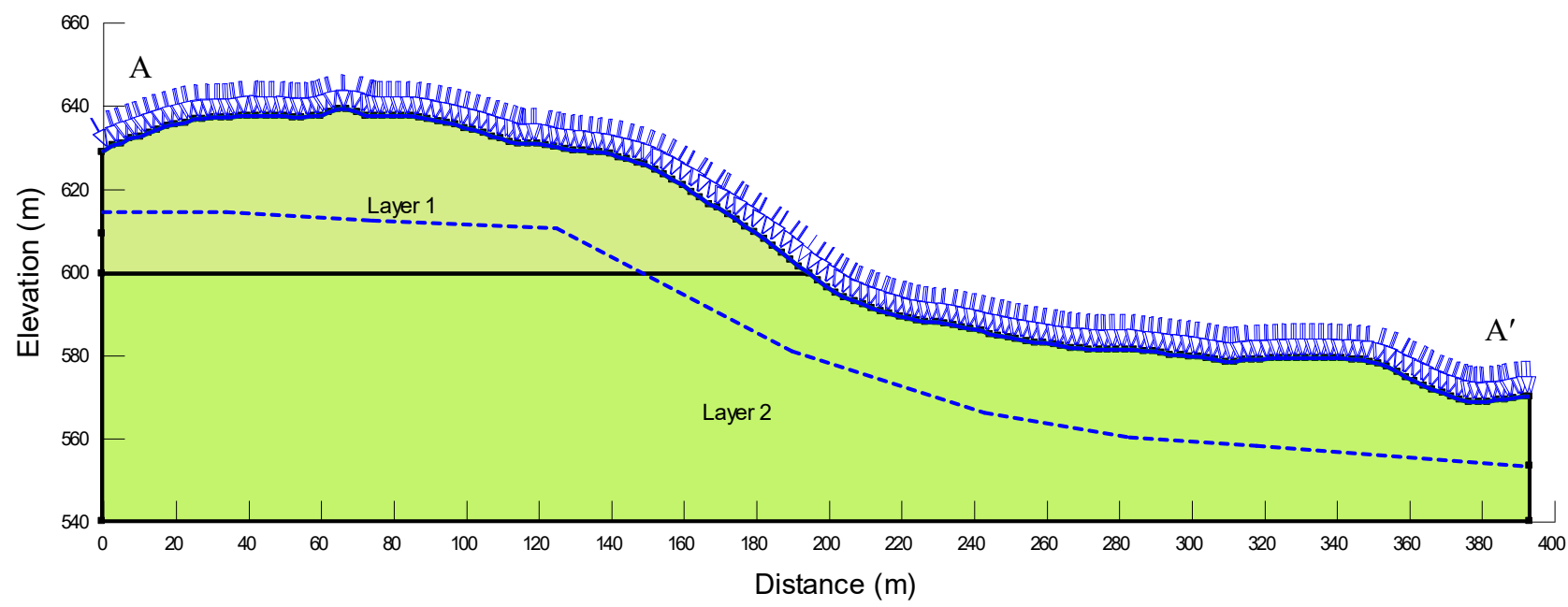

Fig. 5. Slope model scenario (Cross-section A-A') 


\subsection{Back Analysis Results}

Back analysis was conducted to determine the condition when the landslide occurred, i.e. rainfall wetting effect towards the slope stability. When the landslide occurred, it was assumed that the Safety Factor (SF) $\approx 1.00$. The slip surface of the model is adjusted to the conditions of cracks in the field. In ideal condition, the slip surface is determined by field investigation using inclinometer, pipe strain gauge or multi-layer movement meter installed in the borehole. However, due to some constraint, the critical slip surface in this research is decided by Slope/W entry-exit approach, with a fix entry point on the crack at the upper slope. Back analysis was determined by changing the shear strength parameters, such as, cohesion, and internal friction, and also initial groundwater level condition, to get the value of $\mathrm{SF} \approx$ 1.00. The resulting shear strength parameters after the landslide are shown in Table 8 in the green color.

SF value 1.177 is obtained from the calculations of shear strength parameters from the laboratory test results. From the simulation software, back analysis obtained the new value of shear strength parameters with $\mathrm{SF}$ value 1.00 . Based on the result, the new value of cohesion and internal friction are used to simulate the slope condition in the first day on 1 Januari 2018 and the SF value is 1.099 (Table 9).

The principal back analysis is based on the MohrCoulomb Theory. The safety factor is defined as the value of the comparison between the resisting force and the driving force:

$$
F=\frac{c+\sigma \tan \varphi}{c_{d}+\sigma \tan \varphi_{d}}
$$

$c$ and $\varphi$ is the shear strength parameter of the resisting force and $c_{d}$ and $\varphi_{d}$ is the shear strength parameter of the driving force. The safety factor for each component of shear strength, can be stated by the following equation:

$$
\begin{gathered}
F_{c}=\frac{c}{c_{d}} \\
F_{\varphi}=\frac{\tan \varphi}{\tan \varphi_{d}}
\end{gathered}
$$

$F_{c}$ is safety factor of cohesion component and $F_{\varphi}$ is safety factor of internal friction component. In general, the limit equilibrium method assumed that $F_{c}=F_{\varphi}$, in terms of this the components of cohesion and friction were mobilized in the same proportion simultaneously along the landslide field. According to equation above, it obtained the value of shear strength parameter along landslide surface $c_{d}$ and $\varphi_{d}$.

Based on the simulation results (Figure 6), pore pressure distribution for 19 days was obtained, and it increased the groundwater level. Pore-water pressure value distribution data was obtained from vertical section cut on the slope model from the ground surface until the lowest layer. The transformation is shown intuitively by the colors in Figure 6. Above the groundwater level (phreatic line), the pore water pressure was negative, shown in light blue color. Under the phreatic line, the pore water pressure was positive. The lower layer of soil, as well as the higher and more positive pore water pressure value, is shown in the color of blue, green, yellow, and red.

Pore-water pressure value distribution is illustrated in Figure 7a. Pore-water pressure value is changing due to rainfall infiltration into the soil. From the results, the pore-water pressure value decreased when it's

\begin{tabular}{|c|c|c|c|c|c|c|c|}
\hline & \multirow[t]{2}{*}{ Date } & \multirow[t]{2}{*}{ Trial } & \multicolumn{2}{|c|}{ Layer 1} & \multicolumn{2}{|c|}{ Layer 2} & \multirow[t]{2}{*}{ SF } \\
\hline & & & $c\left(\mathrm{kN} / \mathrm{m}^{2}\right)$ & $\varphi\left(^{\circ}\right)$ & $c\left(\mathrm{kN} / \mathrm{m}^{2}\right)$ & $\varphi\left(^{\circ}\right)$ & \\
\hline $\begin{array}{c}\text { Initial Parameter } \\
\text { (Laboratory Test } \\
\text { Result) }\end{array}$ & $9 / 01 / 2020$ & 0 & 11,68 & 18,55 & 11,54 & 15,72 & 1,177 \\
\hline \multirow{8}{*}{$\begin{array}{c}\text { Back Analysis } \\
\text { (Landslide Event) }\end{array}$} & $19 / 01 / 2018$ & 1 & 9,92 & 15,91 & 9,80 & 13,45 & 0,975 \\
\hline & & 2 & 10,24 & 16,24 & 10,17 & 13,77 & 1,002 \\
\hline & & 3 & 10,23 & 16,23 & 10,16 & 13,76 & 1,001 \\
\hline & & 4 & 10,24 & 16,22 & 10,17 & 13,75 & 1,001 \\
\hline & & 5 & 10,24 & 16,21 & 10,17 & 13,75 & 1,001 \\
\hline & & 6 & 10,24 & 16,21 & 10,17 & 13,74 & 1,000 \\
\hline & & 7 & 10,22 & 16,21 & 10,15 & 13,74 & 1,000 \\
\hline & & 8 & 10,21 & 16,21 & 10,14 & 13,74 & 1,000 \\
\hline
\end{tabular}
approaching the groundwater surfaces.

Table 8. Resulting shear strength parameters for each layer 
Table 9. SF value from back analysis shear strength result

\begin{tabular}{clcl}
\hline Day- & SF & Day- & SF \\
\hline 0 & 1,099 & 10 & 1,099 \\
1 & 1,099 & 11 & 1,099 \\
2 & 1,099 & 12 & 1,090 \\
3 & 1,099 & 13 & 1,076 \\
4 & 1,099 & 14 & 1,063 \\
5 & 1,099 & 15 & 1,053 \\
6 & 1,099 & 16 & 1,043 \\
7 & 1,099 & 17 & 1,030 \\
8 & 1,099 & 18 & 1,015 \\
9 & 1,099 & 19 & 1,000 \\
\hline
\end{tabular}

Pore-water pressure under the groundwater surfaces has a positive value and increased when getting further from the groundwater surfaces.
Pore-water pressure has a negative value if the position is above the groundwater surfaces or in the relatively dry area. Water infiltrates into the soil, fills cavities that were once filled by air. Furthermore, porewater, which initially has negative (dry) value, shifted into positive value as the soil saturation degree increased.

The rise of groundwater-surface leads the SF value of the slope to decrease. According from the soil properties data, the safety factor of the initial condition of the slope was 1.099, and it was already unstable. The safety factor value did not change until day 11 , and then it started to decrease. On the day when the landslide occurred, the SF value was 1.00. The rainfall effect made SF value decreased-hence triggering the landslide. Figure $7 \mathrm{~b}$ illustrates the SF data from the groundwater-surface transformation in 19 days.

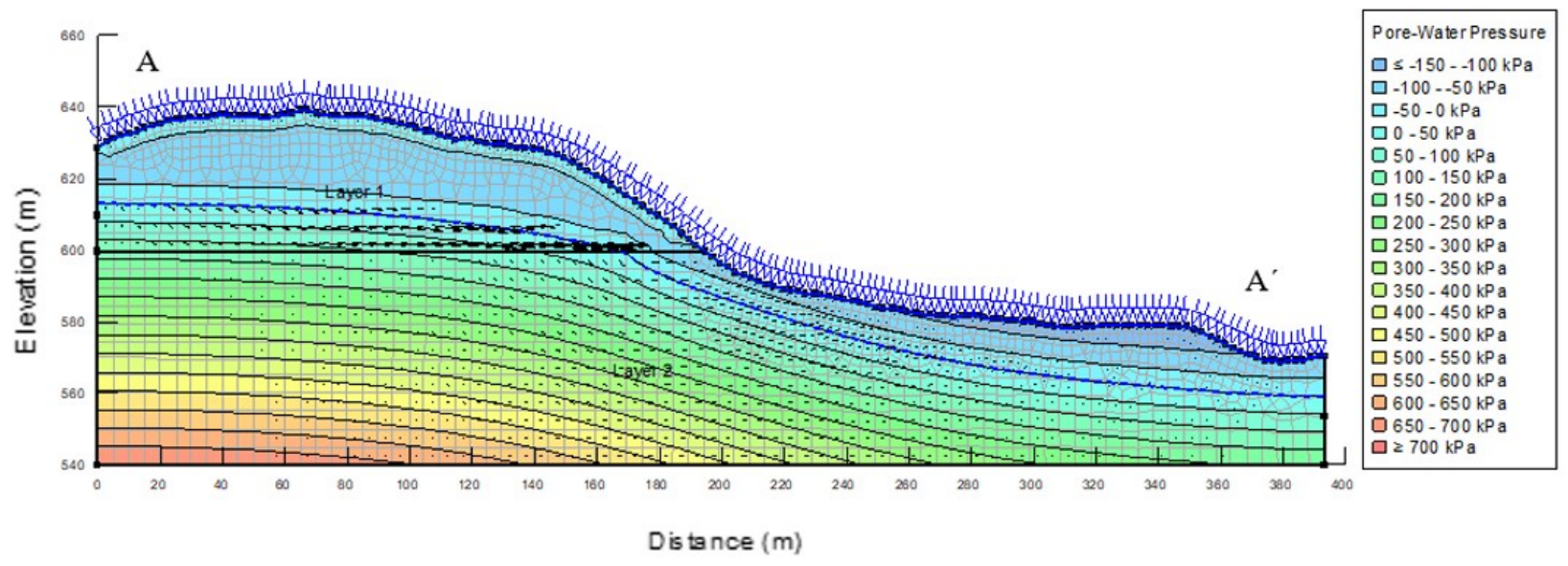

Fig. 6. Pore-water pressure condition on the $19^{\text {th }}$ day (number show the value of pore-water pressure in kPA)

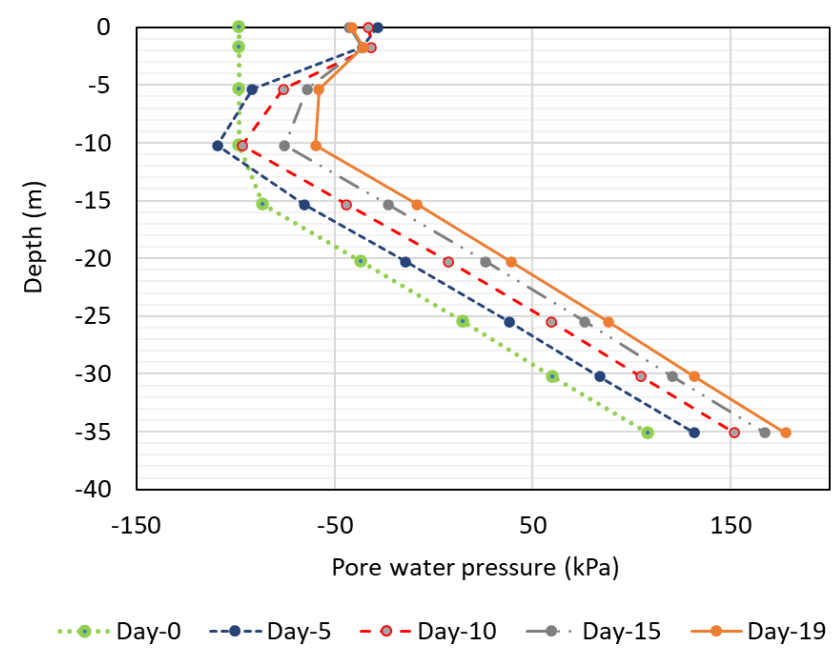

(a)

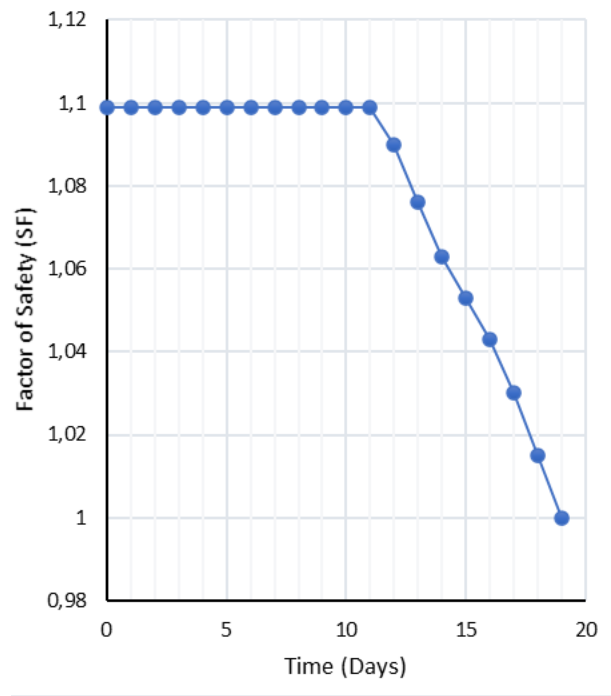

(b)

Fig. 7. (a) Pore-water pressure distribution (b) SF value distribution on 1 - 19 January 2018 


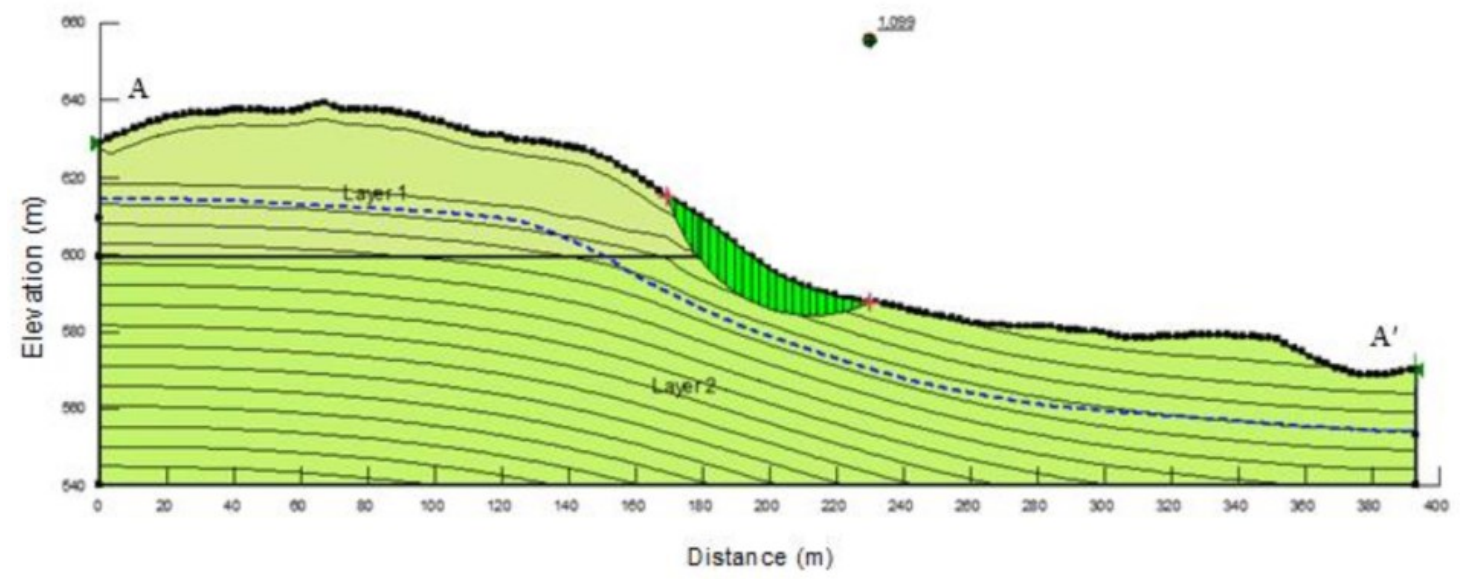

Fig. 8. SF value on the $1^{\text {st }}$ day

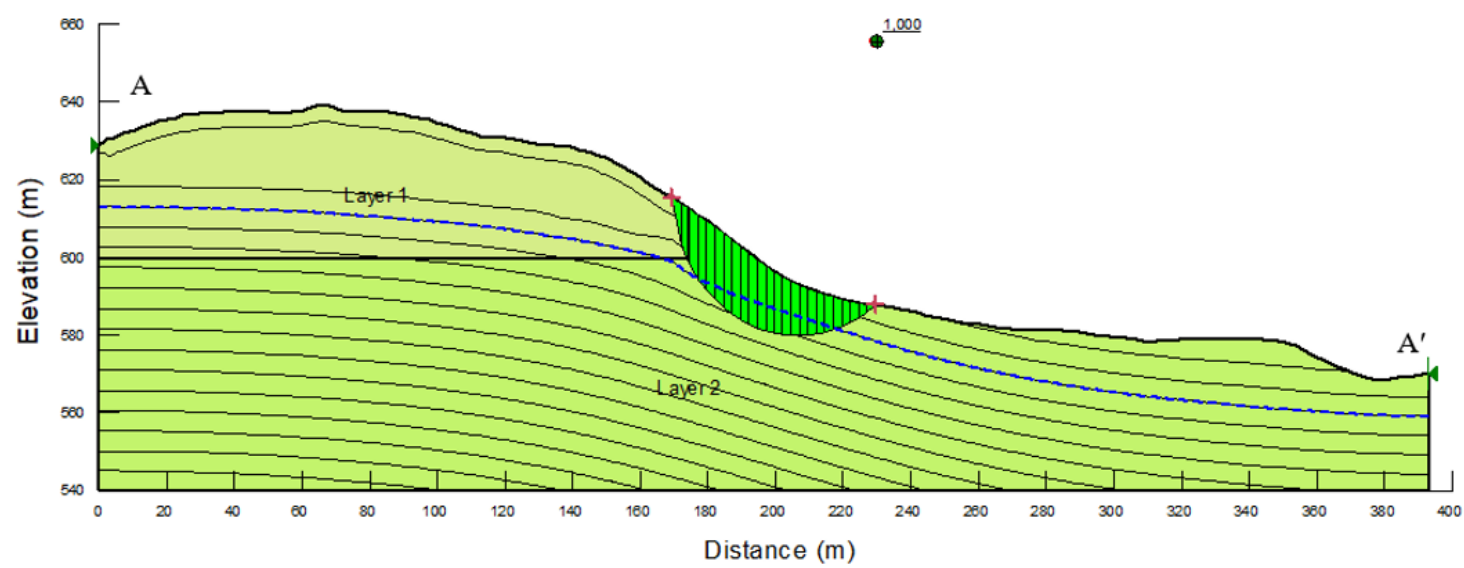

Fig. 9. SF value on the $19^{\text {th }}$ day

Simulation results of the slope on the day 1 and 19 are presented in Figure 8 and Figure 9. The slip surface of both figure are used entry-exit point, which the entry point is assumed by the crack location in the field, and the exit point is got from back analysis result. In Figure 8 , the groundwater has not reached the slip surface. The groundwater reached the slip surface on the day 12 and keep going up until the day 19 (Fig.9), and the slope can not hold the driving force and finally landslide occured.

\subsection{Mitigation Recommendation for Risk Reduction}

As a structural mitigation effort, the recommendation to minimize the risk of the landslide is to adjust the slope geometry. A slope is classified as safe/stable from landslide occurrence if the safety factor value is above 1.25. Based on back analysis results, the current landslide condition was under 1.25 , i.e., 1.099. The slope mass was not 'sliding,' yet it was critical and can move when a triggering factor presented. Transformation of the slope geometry to increase the safety factor is one of structural mitigation works. The suitable method is 'cut and fill', in which part of the slope is cut and used as the counterweight. This mitigation work is used as a recommendation that could be implemented by related institutions. Another alternative mitigation is a comprehensive early-warning system containing seven sub-systems corresponding to ISO 22327:2018 [17] and SNI 8235 [18]. Non-structural mitigation effort can be implemented if there is no sufficient capability to apply expensive structural mitigation.

The early-warning system should be bounded up with locals to empower the threatened individual and society. Early warning system will be effective and comprehensive if the development is conducted on 7 sub-systems: risk assessment, socialization, forming disaster prepared responder team, operational evacuation guide, composing a standard procedure, monitoring, early warning, evacuation rehearsal, and developing local authorities' and community's commitment towards operation and management of landslide early warning system [3] [17] [18].

\section{Conclusions}

According to the results of analysis, it can be concluded that the rainfall wetting could affect the slope stability. Rainfall wetting caused the slope stability or safety factor value decrease. One of the main factors causing SF value degradation was the increase of groundwater surfaces caused by the rainfall infiltration into the soil. In addition, saturated condition decreased the soil shear 
strength. From the analysis, the initial slope condition was unstable, with SF value was 1.099.

After 19 days with heavy rainfall at a day before the landslide occurred, the daily accumulated rainfall reached $54.81 \mathrm{~mm}$. A few days before the event, on the day 3 and 4, the daily accumulated rainfall was 60.69 and $82.03 \mathrm{~mm}$ respectively and classified as heavy rain. Based on back analysis using hydraulic conductivity parameters as input and initial groundwater surfaces condition modeling, the SF value was 1.00 when the landslide occurred. SF value decreased because the pore-water pressure value changed due to rainfall infiltration. Water infiltrated into the soil and filled cavities that once were filled by air. Pore-water pressure, which initially has a negative (dry) value, shifted to positive value as the soil saturation degree increased.

Several mitigation efforts can be applied, such as structural mitigation, i.e., cut and fill and non-structural mitigation, namely a comprehensive early warning system. This research will be carried out to the next stage to analyze the effect of rainfall on the groundwater condition using tank models and compared with the hydraulic conductivity method. The results of the analysis will be used as a parameter for early warning landslide induced by rainfall.

This research is supported by the scholarship of Indonesian Endowment Fund for Education (LPDP — Lembaga Pengelola Dana Pendidikan) from the Indonesian Ministry of Finance

\section{References}

1. PVMBG, Database of Volcanology Centre and Geology Disaster Mitigation, Yogyakarta: PVMBG, 2019. (in Bahasa)

2. BPBD Magelang, "Disaster Data Monitoring BPBD Magelang," 2018. [Online]. Available: http://bpbd.magelangkab.go.id. [Accessed date 12 November 2019]. (in Bahasa Indonesia)

3. T. F. Fathani, D. Karnawati and W. Wilopo, "An Integrated methodology to develop a standard for landslide early warning system," Nat. Hazards Earth Syst. Sci., pp. 2123-2135, 2016.

4. D. Ariesta, Study on The Impact of Initial Water Table and Rainfall-Wetting Process to The Slope Stability, Yogyakarta: Tesis, Magister Teknik Pengelolaan Bencana Alam UGM, 2018. (in Bahasa)

5. T. A. Bui, T. F. Fathani and W. Wilopo, "Landslide Risk Assessment for Designing Monitoring and
EarlyWarning System," J. Appl. Geology vol. 4, 2019.

6. F. Faris and T. F. Fathani, "A Coupled Hydrology/ SLope Kinematics Model for Developing Early Warning Criteria in the Kalitlaga Landslide, Banjarnegara Indonesia," Progress of GeoDisaster Mitigation Technology in Asia, vol. 2, 2013.

7. M. T. Naing, T. F. Fathani and W. Wilopo, "Estimating the Velocity of Landslide Movement Using Visco-Plastic Model in Jeruk Sub-village, Kulon Progo District, Yogyakarta, Indonesia,' Journal of The Civil Engineering Forum, vol. 4, no. 3, 2018 .

8. R. Hidayat, "Slope Stability Analysis in Caok Village Landslide," Jurnal Sumber Daya Air, vol. 14, pp. 63-74, 2018. In Bahasa

9. H. C. Hardiyatmo, Landslide and Erosion (Occurrence and Countermeasure), Yogyakarta: Gadjah Mada University Press, 2012.

10. H. Rahardjo, "Effectiveness of Horizontal Drains for Slope Stability," Eng. Geol, vol. 69, pp. 295 308, 2003.

11. J. Peranić, "Rainfall Infiltration and Stability Analysis of An Unsaturated Slope in Residual Soil from Flysch Rock Mass," Proceedings of XVII European Conference on Soil Mechanic and Geotechnical Engineering, 2019.

12. Directorate General of Reforestation and Land Rehabilitation, Guidance of Land Rehabilitation and Conservation, Jakarta: Forestry Department, 1986. (in Bahasa Indonesia)

13. H. C. Hardiyatmo, Soil Mechanics 1, Yogyakarta: Gadjah Mada University Press, 2017. (in Bahasa)

14. R. Munoz-Carpena, C. M. Regalado, J. AlvarezBenedi and F. Bartoli, "Field Evaluation of the New Phillip-Dunne Parameter for Measuring Saturated Hydraulic Conductivity," Soil Sci., vol. 167, pp. 9-24, 2002.

15. B. M. Das, "Advanced Soil Mechanics," New York, McGraw-Hill, 1985.

16. B. Triatmodjo, Applied Hydrology, Yogyakarta: Beta Offset, 2014. (In Bahasa)

17. ISO 22327, Security and resilience - Emergency management - Guidelines for implementation of a community-based landslide early warning system, Switzerland: International Organization for Standardization, 2018.

18. SNI 8235, Landslide Early Warning System, Jakarta: Badan Standardisasi Nasional, 2017. (in Bahasa) 